\title{
Basic Principles and Ecological Consequences of Changing Water Regimes on Nitrogen Cycling in Fluvial Systems ${ }^{1}$
}

\author{
GILLES PINAY* \\ JEAN CHRISTOPHE CLÉMENT \\ UMR ECOBIO \\ University of Rennes I, Campus de Beaulieu \\ Avenue du général Leclerc \\ F-35042 Rennes cedex, France
}

\section{ROBERT J. NAIMAN}

School of Aquatic and Fishery Sciences, Box 355020

University of Washington

Seattle, Washington 98195, USA

ABSTRACT / Understanding the environmental consequences of changing water regimes is a daunting challenge for both resource managers and ecologists. Balancing human demands for fresh water with the needs of the environment for water in appropriate amounts and at the appropriate times are shaping the ways by which this natural resource will be used in the future. Based on past decisions that have rendered many freshwater resources unsuitable for use, we argue that river systems have a fundamental need for appropriate amounts and timing of water to maintain their biophysical integrity. Biophysical integrity is fundamental for the formulation of future sustainable management strategies. This article addresses three basic ecological principles driving the biogeochemical cycle of nitrogen in river systems. These are (1) how the mode of nitrogen delivery affects river ecosystem functioning, (2) how increasing contact between water and soil or sediment increases nitrogen retention and processing, and (3) the role of floods and droughts as important natural events that strongly influence pathways of nitrogen cycling in fluvial systems. New challenges related to the cumulative impact of water regime change, the scale of appraisal of these impacts, and the determination of the impacts due to natural and human changes are discussed. It is suggested that cost of longterm and long-distance cumulative impacts of hydrological changes should be evaluated against short-term economic benefits to determine the real environmental costs.
Floodplain, riparian, and instream zones are important components of river ecosystems (Hynes 1975, Ren and others 2000, Décamps 1996, Triska and others 1993, Sparks 1995, Naiman and Décamps 1997). These riverine and instream zones are intimately linked to the efficient functioning of rivers, and the timing and duration of flood and low flow events largely control their existence and maintenance (Salo and others 1986, Junk and others 1989, Gregory and others 1991). Among other processes, floodplain, riparian and instream zones contribute to shaping and maintaining water quality (Peterjohn and Correll 1984, Brinson and others 1984, Triska and others 1989). However, a change in the natural water regime will affect the biogeochemistry of riparian and instream zones as well as their

KEY WORDS: Nitrogen cycling; Biogeochemical cycle; Fluvial ecosystems; Flow regime; Ecological principles; Watershed management; Rivers; Research challenges

\footnotetext{
${ }^{1}$ This is a contribution of the Scientific Committee on Water Research (SCOWAR) of the International Council for Science (ICSU).

*Author to whom correspondence should be addressed; email: gilles.pinay@univ-rennes1.fr
}

ability to cycle and mitigate nutrients fluxes originating from upstream and upslope. The effects of water regime changes on the biogeochemistry of river systems have been demonstrated at local scales (Triska and others 1993, Pinay and others 1995, Hedin and others 1998, Hill and others 2000). However, the managerial challenge is to evaluate the effects of these changes at larger scales corresponding to the entire watershed or landscape.

The watershed scale necessitates identification of fundamental principles driving nutrient-related biogeochemical processes in river ecosystems, with the goal of providing general rules of functioning that can be translated into management practices. These principles have to be simple but robust and formulated in a pragmatic way to support sustainable water management and thoughtful political decisions. In this article we define three fundamental principles driving the nitrogen cycle in river systems. In general, these principles should apply to other nutrients (Hedin and others 1998). As examples, we analyze the consequences of water regime changes on nitrogen cycling and fluxes in riparian, floodplain, and instream zones, keeping in mind that changes in water regime also affect other 
intimately linked biogeochemical cycles. At the hydrosystem scale, the three fundamental principles that regulate the cycling and transfer of nitrogen in rivers are: (1) the mode of nitrogen delivery affects ecosystem functioning, (2) increasing contact between water and soil or sediment increases nitrogen retention and processing, and (3) floods and droughts are natural events that strongly influence pathways of nitrogen cycling.

\section{The Mode of Nitrogen Delivery Affects River Ecosystem Functioning}

The first principle is related to the delivery patterns of nitrogen inputs along river corridors. River systems and their riparian zones can be viewed as open ecosystems dynamically linked longitudinally, laterally, and vertically by hydrologic and geomorphic processes (Ward 1989). In small, forested headwater streams, particulate organic nitrogen is the main form of nitrogen transferred to the aquatic system, primarily as litter fall from the adjacent riparian vegetation (Cummins and others 1983, Minshall and others 1983). Nitrogenfixing plants such as alder (Alnus spp.) are often found in riparian forests (Décamps 1993). They contribute large amounts of nitrogen rich organic matter, which can reach several kilograms of dry matter per square meter (Chauvet 1987). Eventually these particulate inputs contribute to the export of dissolved organic nitrogen via surface and subsurface pathways after degradation and recycling processes have occurred (Newbold and others 1981, Elwood and others 1983, McClain and others 1997, Clark and others 2000, Stepanauskas and others 2000). Due to their location along the edge of rivers, riparian forests also receive, recycle, and transfer large amounts of sediments and nutrients to streams (for nitrogen, it is mainly as nitrate by subsurface flow) from up-slope ecosystems (Peterjohn and Correll 1984, Lowrance and others 1995). Fortunately, riparian zones can efficiently utilize and retain nitrate inputs from up-slope as long as the subsurface water flow intercepts roots and microorganisms. Therefore riparian zones deliver nitrogen to streams mainly as particulate organic matter.

Riparian zones also effectively utilize and retain nitrogen moving upstream in the bodies of migrating animals. In the United States Pacific Northwest, the role of millions of salmon in transferring nutrients from marine to freshwater environments has been long recognized (Juday and others 1932). More than $95 \%$ of the Pacific salmon body mass is accumulated from the marine environment (Groot and Margolis 1991). This material is transported and deposited in freshwater habitats where salmon spawn and die, providing an

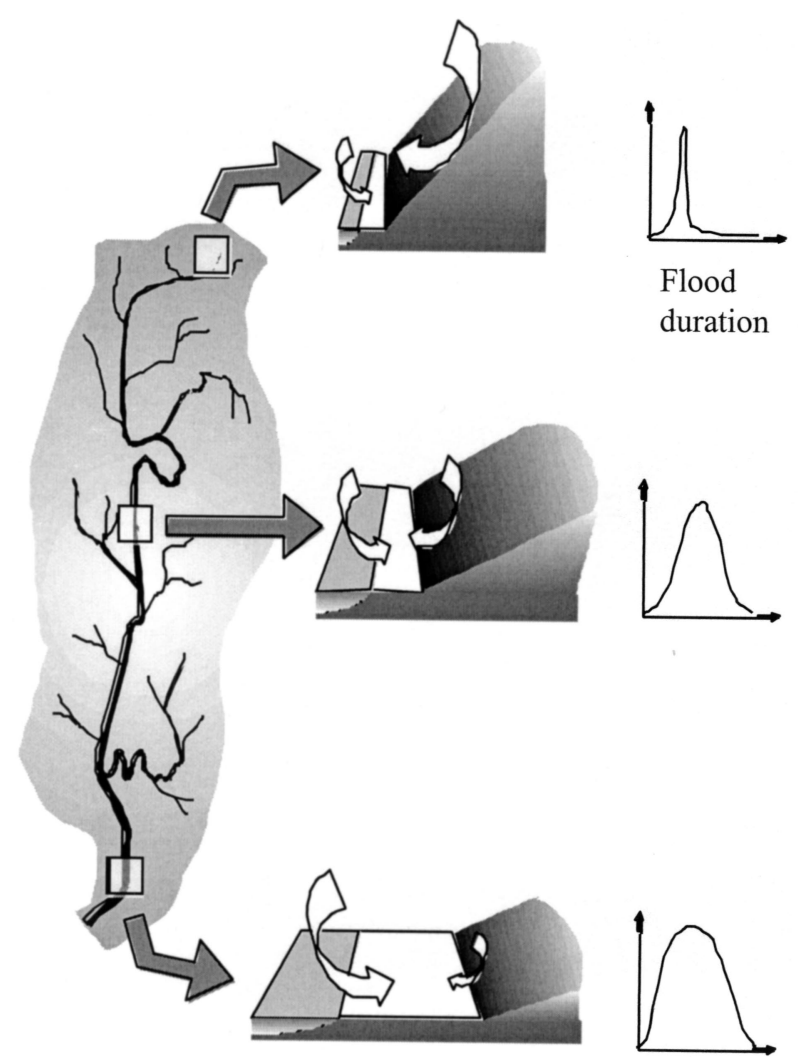

Figure 1. Preferential water and nutrient movements through the riparian zones as a function of their location within the drainage basin (adapted from Tabacchi and others 1998). Arrows symbolize the main water and associated suspended and dissolved matter transfers between upland and stream via the riparian zone. Riparian zones are in white, rivers in light gray and the upland catchments in dark gray. Along small streams most of the water and associated nutrients flow from the upland via the riparian zone whenever it exists, while along larger streams the main flow direction is from the stream toward the floodplain (mainly during flood events).

important nutrient subsidy to oligotrophic freshwater (Gresh and others 2000) and riparian ecosystems (Helfield and Naiman 2001) throughout the region.

In the floodplains of most large rivers, the main inputs of nutrients, sediment, and organic matter are mainly via surface flow from upstream (Figure 1). Indeed, significant amounts of these materials are deposited during floods (Brinson and others 1983, Schlosser and Karr 1981, Lowrance and others 1986, Grubaugh and Anderson 1989, Brunet and others 1994). River floodplains are recognized as important storage sites for sediments and associated nutrients mobilized from upstream catchments during floods (He and Walling 1997). The transfer and storage of materials in flood- 
plains are largely under the control of flood duration, frequency, and magnitude that, collectively, create a mosaic of geomorphic surfaces influencing the spatial pattern and successional development of riparian vegetation (Salo and others 1986, Roberts and Ludwig 1991). The flux of matter via flood deposits is responsible for the high nutrient cycling capacity of floodplain soils, as compared to upland ecosystems (Brinson and others 1984). The significantly higher fertility of floodplain soils is illustrated in an agricultural example from Bangladesh. Historically, flood-mediated sediment and nutrient deposits on the Ganges and Bramaputhra river floodplains supported up to three crops of rice per year without fertilizer addition, while upland soils only sustained one crop a year (Mathab and Karim 1992, Haque and Zaman 1993).

In human-impacted catchments, nitrogen generated by human activities often overwhelms natural nitrogen fluxes (Meybeck 1982, Nixon and others 1996). Moreover, changes to the hydrologic regime by dams have had strong impacts on nitrogen-related processes. Dammediated impacts have occurred in most of the large rivers of the Northern Hemisphere (Dynesius and Nilsson 1994, Graf 1999) as well as in many African and Asian rivers (Petts 1990, Pringle and others 2000). Dams have significant effects on water regimes by reducing the magnitude and frequency of flood events and by changing their periods of occurrence (Stanford and Ward 1988). For instance, the Faraka Dam on the Indian side of the Ganges River has changed the timing of floods, significantly limiting rice production in the Bangladesh region of the Ganges floodplain. Moreover, it is suspected that proposed plans of river regulation to prevent flood "damages" within Bangladesh would quickly diminish floodplain soil fertility, rendering this country even more dependant on foreign food supplies within two decades. Hence, if population protection against floods is necessary, it can be done best by establishing dikes around villages and building concrete shelters. However, if environmental quality is to be maintained, it is essential to retain the natural flood regimes of the Ganges and Bramaputhra rivers, which sustain the natural soil fertility of the floodplains.

Additionally, impoundments accumulate sediments behind the dams, limit lateral channel migration downstream that is responsible for many ecological processes (Shield and others 2000), and deplete floodplain soils by erosion for hundreds of kilometers further downstream. As a result, river floodplains shift from being a sink to a source of sediment and nutrients, reducing the river ecosystem's retentiveness of nutrients and its overall fertility. In the Nile River floodplain, following construction of the Aswan Dam, the lack of annual sediment deposition together with the new need for irrigation has led to high salt accumulations on a large part of the area. These areas are now of no further agricultural use (Evans 1990). An additional example is provided by the construction of the Iron Gate I and II dams in the middle reach of the Danube River between Serbia and Romania in the late 1950s. Since the dam's construction, there has been a significant decrease in the sediment load of the Danube River. As a consequence, the lack of a continuous sediment supply has caused lateral bank erosion that can be measured more than $1000 \mathrm{~km}$ downstream. Unfortunately, the bank erosion that creates severe local problems of bank stability is not enough to compensate for the lack of natural sediment transport to the Danube Delta, which is being increasingly eroded by Black Sea currents along the Romanian coast (Vadineanu and others 1987). Examples such as these suggest that cost of long-term and long-distance cumulative impacts of large dams should be evaluated against short-term economic benefit to determine the real costs to the environment and to human populations.

\section{Increasing Contact Between Water and Soil or Sediment Increases Nitrogen Retention and Processing}

The second basic principle is that the area of watersubstrate interface (i.e., water-sediment or wetlandupland length of contact) is positively correlated with the efficiency of nitrogen retention and use in river ecosystems. This occurs both instream and in the riparian and floodplain zones. The nitrogen cycle is driven by processes that occur on or at the interface of particulate material such as stones, soils, sediments, or algal mats (Ponnamperuma 1972, Hill 1979, Jones and Holmes 1996, Valett and others 1996). Hence, the length or the duration of contact between water and these substrates increases the biological use and thereby the total amount of nitrogen processed.

There is empirical evidence showing that the rate of instream nitrogen cycling depends on the surface contact of water with sediment as well as the duration of contact. In a recent cross-stream comparison in different biomes of North America, Peterson and others (2001) found the most rapid uptake of ammonium in the smallest streams. The underlying reason is that the high surface-to-volume ratios of small streams favor uptake and removal processes of nitrogen. This is in accordance with the results of Wollheim and others (2001), who found a positive relationship between stream discharge and ammonia travel distance in Alas- 


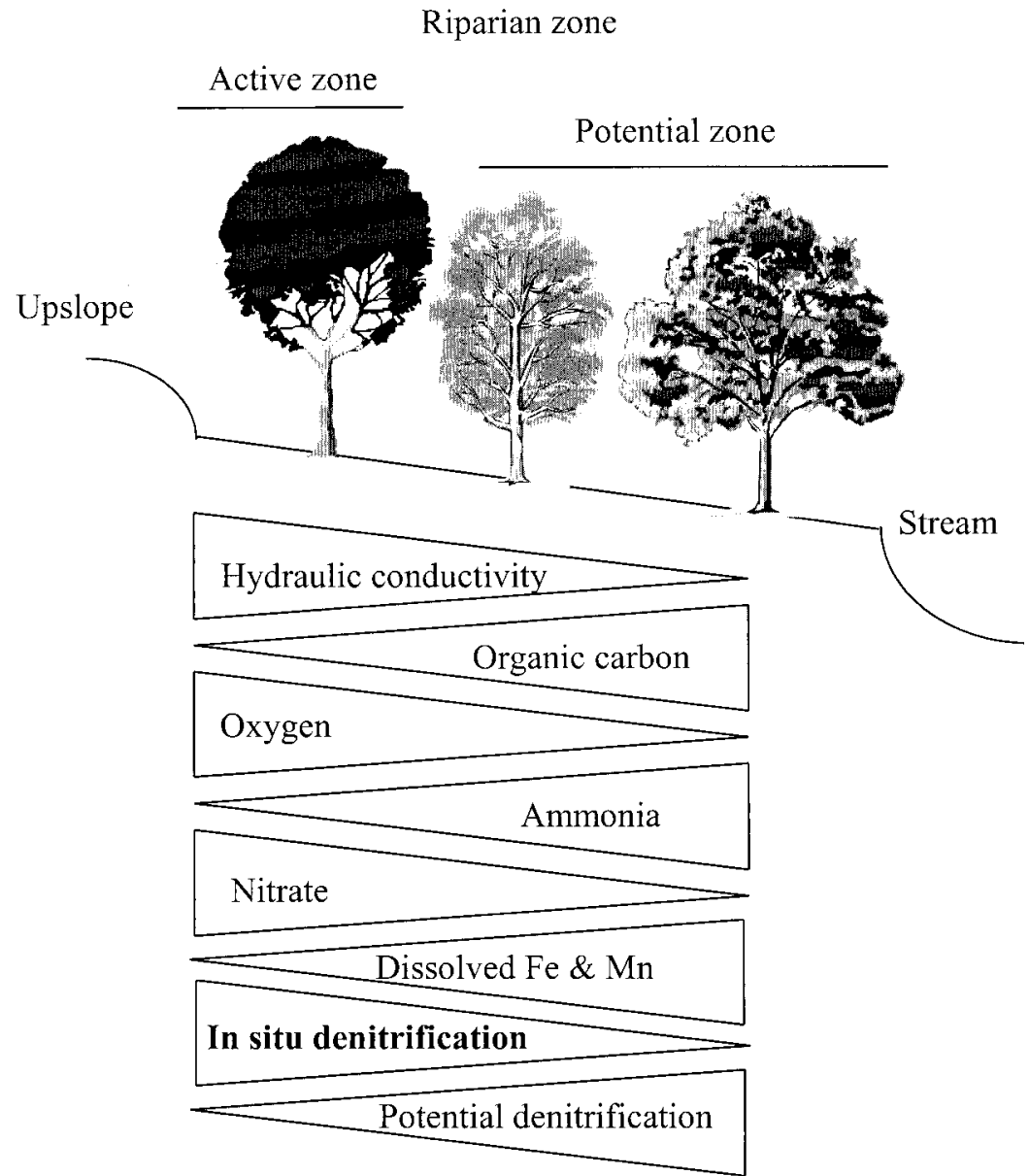

Figure 2. Biogeochemical gradients at the upland-riparian wetland interface. kan streams. This means that in larger streams, a given ammonia molecule will travel for a longer distance before being involved in a biogeochemical process such as plant uptake, nitrification, or adsorption to the sediment. The travel distance will depend also on the type of nitrogen molecule. Peterson and others (2001) measured nitrate molecules traveling, on average, about 10 times farther than ammonia molecules. Overall, it is now understood that headwater streams retain and transform significantly more nitrogen per unit surface area than large rivers (Alexander and others 2000).

Hyporheic zones, which represent aquifers beneath the riverbed where surface and ground water mix, are also highly reactive sites for nutrient cycling since they expand the surface of contact between water and sediment (Edwards 1998, Triska and others 1989). The hyporheic zone, which can extend laterally a great distance from the riverbed (Stanford and Ward 1988), is constituted of a mixture of coarse and fine sediments. The hyporheic sediments within the active channel are rearranged during strong floods, which create subsur- face conduits of high hydraulic conductivity. The porous media of hyporheic zones provide an important exchange surface where microbes develop and actively participate the nutrient recycling processes, depending on the extent of hyporheic flow and its exchanges with surface water (Triska and others 1990). The degree of exchange depends on the hydraulic characteristics of the river channel; usually physical heterogeneity such as meanders or riffle-pool sequences promote greater exchange rates (Jones and Holmes 1996).

Riparian wetlands also provide a large contact area between water and soils that promote nitrogen retention and processing, thereby regulating fluxes from uplands to streams. The wetland-upland contact zone can be envisioned, as a first approximation, as the contact zone between the riparian wetland and the uplands (Figure 2). This zone of contact varies both in depth and width as a function of the river's geomorphology and hydrologic regime. During high water periods, the extension of the wetted area increases laterally from the stream and extends further upstream, 
Figure 3. Nitrogen cycle in wetland soils.

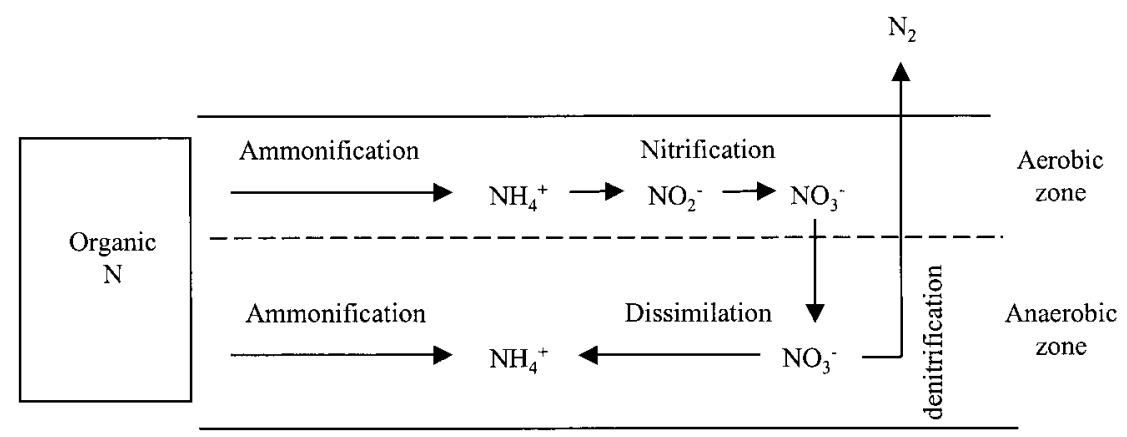

while during low water periods, the wetted area shrinks in width and decreases in length upstream (Beven and Kirkby 1979).

There has been considerable interest in restoring or promoting the use of riparian wetlands to mitigate diffuse nutrient pollution (Peterjohn and Correll 1984, Lowrance and others 1985, Pinay and Labroue 1986, Haycock and others 1997). Surprisingly, several attempts to relate the percentage of riparian wetlands with nutrient fluxes at the outlet of drainage basins have failed (Osborne and Wiley 1988, Tufford and others 1998). One of the major reasons for the lack of correlation is that riparian efficiency is driven by hydraulic connection with upland inputs since nitrate is often a limiting nutrient (Groffman and Hanson 1997, Lowrance and others 1997). Riparian zones represent a mosaic of physical and functional units whose patterns are shaped by long-term geomorphic development of the floodplain. These biophysical units can be connected or disconnected hydrologically from each other and from the upland catchment (Brinson 1993). Therefore, the efficiency of a riparian zone in regulating nitrogen fluxes is not a function of the surface area of the riparian zone but rather a function of the hydrological length of contact between the riparian zone and the upland drainage basin (Haycock and Pinay 1993, Matchett 1998).

This can be illustrated by comparing first-order streams (i.e., small perennial streams without any tributaries) to larger rivers. First-order streams represent more than $50 \%$ of the entire length of the river network, while higher-order rivers represent only a few percent of the total length in a given catchment (Naiman 1983). As a consequence, riparian zones associated with small-order streams develop a more intimate wetland-upland interface than riparian zones along high-order rivers (Brinson 1993) and better contribute to mitigating diffuse pollution from the catchment (Peterson and others 2001). Moreover, for a given total surface of riparian zone in a catchment, small streams are more efficient in retaining upland nutrients than larger streams because of the close proximity of water to sediments or soils.

Throughout the world, many upland streams have been subjected to human modifications such as channelization, impoundment, or removal of riparian vegetation. All anthropogenic impacts tend to reduce both the spatial extent of wetted areas and the duration of riparian soil saturation (Worrall and Burt 1998). Moreover, straightening river channels, dredging riverbeds, or clogging of interstitial spaces by fine sediments reduces the size of the hyporheic zone and its exchange rates with surface water, thereby affecting the nutrient recycling capacity of the stream. As a consequence, these human-driven alterations reduce the efficiency of the river network to mitigate diffuse nutrient pollution.

\section{Floods and Droughts are Natural Events that Strongly Influence Pathways of Nitrogen Cycling}

The third principle is related to the role of floods in shaping the characteristics of nitrogen cycling. Changes to the water regime, either through alterations in the frequency, duration, period of occurrence, and intensity of water levels, directly affect nitrogen cycling in alluvial soils by controlling the duration of oxic and anoxic phases (Ponnamperuma 1972, Keeney 1973, Patrick 1982). Flooding duration is controlled by local topography; low areas are flooded more often and longer than higher ones, producing variations in biogeochemical patterns at the meter scale (Pinay and others 1989, Pinay and Naiman 1991). Biogeochemical processes, especially for nitrogen, are sensitive to the oxido-reduction status of the soil (Figure 3). For instance, ammonification of organic nitrogen can be realized both under aerobic and anaerobic conditions, but the nitrification process, which requires oxygen, can only occur in aerated soils or sediments. As a consequence, under permanently anaerobic conditions, the organic nitrogen mineralization process re- 

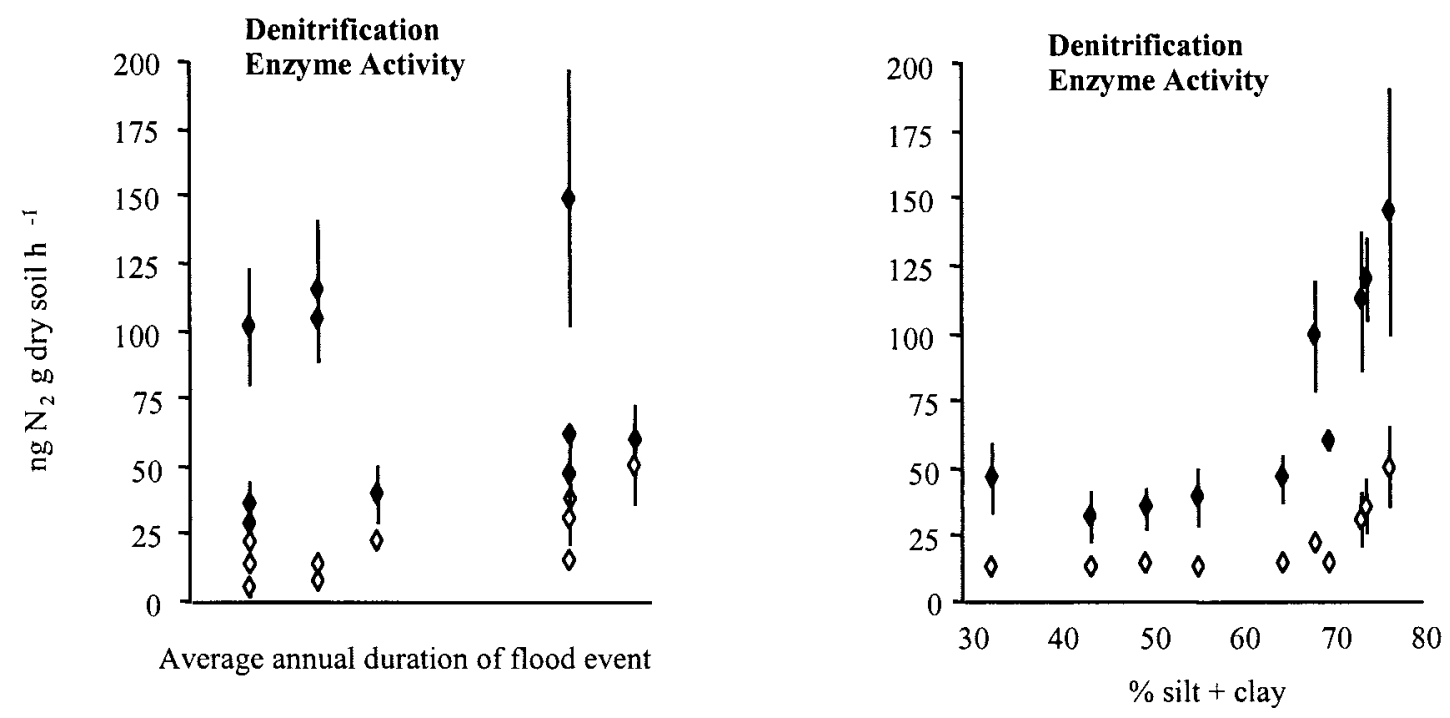

Figure 4. Denitrification enzyme activity in floodplain soils as a function of the average annual duration of flood event and as a soil percentage of silt + clay. Open symbols represent the potential denitrification activity under anaerobiosis with nitrate addition. The closed symbols represent the potential denitrification activity under anaerobiosis with nitrate and glucose addition.

sults in the accumulation of ammonia. Other processes, such as nitrogen dissimilation or denitrification, are strictly anaerobic, requiring saturated soils to operate. Therefore the end products of nitrogen cycling in riparian soils are under the control of the moisture regime (e.g., groundwater table), with important implications for floodplain productivity.

Short-term periodicity of aerobic-anaerobic conditions through groundwater level movements allows all nitrogen cycling processes to occur simultaneously at the same location in accordance with the level of soilwater saturation. Several studies have demonstrated that alternating aerobic and anaerobic conditions enhance organic matter decomposition and nitrogen loss through denitrification (e.g., Reddy and Patrick 1975, Groffman and Tiedje 1988). Moreover, it has been shown in an experimental study that the marsh organic nitrogen mineralization rate is much greater during a flooded period than during a non-flooded one (Neill 1995). Overall, natural water table fluctuations in floodplains are key drivers of soil fertility, with changes to the natural flood regime often decreasing productivity. However, drier periods also are important since they allow mineralization of more complex organic matter structures (e.g., hemicellulose and lignin) and contribute to soil fertility by providing another inorganic nitrogen source (ammonia and nitrate) to plant and microbes which otherwise would be sequestered as organic residues.

The flood regime also indirectly affects nutrient cycling in floodplain soils by influencing soil structure and texture through the deposition of sediment. The alluvial soil grain size mosaic and the proportion of different grain size deposits varies spatially and temporally following extreme flooding (Petts and Maddock 1996, Richter and Richter 2000). At small scales, geomorphic and hydrologic processes influence the sorting of sediment deposits on a grain-size basis, creating a mosaic of soils of different textures. It is the soil or sediment texture that influences denitrification rates as well as other biogeochemical cycles (Pinay and others 2000). Fine structures such as clay develop large surface areas per unit of weight or volume, which provide greater chemical adsorption sites (Paul and Clark 1996) and microbial habitats (Ranjard and others 2000). For instance, the fastest denitrification rates are measured in soils with fine texture. Below a threshold of $\sim 65 \%$ silt and clay, floodplain soils do not show any significant denitrification (Figure 4). Above that threshold, denitrification increases linearly. In fine-textured floodplain soils, denitrification rates are of the same order of magnitude as nitrogen mineralization, with annual denitrification representing up to $50 \%$ of the nitrogen deposited during floods (Pinay and others 1995). Thus floodplains contribute to the regulation of nitrogen fluxes by sorting sediments mobilized during floods and recycling nitrogen deposited during a flood.

\section{General Applicability of Principles}

Do these three principles apply in all climates? Yes, but the nitrogen process rates vary among climates. For 
example, in temperate and wet tropical areas, nitrate fluxes are rather constant. Under such climate conditions allochthonous nitrate seems to be completely removed within a few meters of travel in the riparian zone (Pinay and others 1993, McClain and others 1997). Under harsher continental conditions, high nitrate fluxes occurring during the spring thaw pass through the riparian zone largely unprocessed because cold temperatures limit both denitrification and plant uptake. Similarly, little nitrogen processing occurs during transport from upland through riparian zones in arid areas (Holmes and others 1994). Thus the riparian zone is rather ineffective in initial retention of upland nitrogen inputs in continental and in arid climates, in part because overland flow rapidly transports water and nitrogen across the riparian surface during storms (Décamps and others 2002). Even though nitrogen process rates vary along climates, the three basic principles driving nitrogen regulation in riparian wetland remain valid, and riparian zones should be promoted, even though their $\mathrm{N}$ buffering capacity is not proved, since they perform many other functions (Naiman and Décamps 1997).

\section{New Challenges}

Improvement in our knowledge of the ecological consequences of changing water regimes on nitrogen cycling in riparian zones raises several new scientific challenges. These challenges relate to the cumulative impacts of water regime changes, the scale of appraisal of these impacts, and determining the relative impacts due to natural and human changes.

Quantifying the cumulative effects of water regime changes on alluvial soil biogeochemistry is an important scientific challenge. For instance, a reduction in the duration of the high water period along low-order streams would lead to downslope movement of the dry-wet interface within the riparian zones, thereby favoring further intrusion of upland allochthonous nitrates within the riparian zones (Burt 1997). Moreover, it is expected that this intrusion will lead to further incursion of pesticides in riparian soils as well since these xenobiotic molecules are often found together with nitrate. To what extent does this intrusion reduce bacterial denitrification of newly contaminated soils where pesticide decomposition would be less effective since the bacterial population was not adapted to repeated pesticide application (Abdelhafid and others 2000)? Another aspect of this challenge is related to an increase in the occurrence extreme flood events. This would reduce the amount of fine-textured sediment deposited, especially in constrained floodplains, thereby reducing floodplain soil productivity. The lack of fine-textured sediments would also reduce the heavymetal adsorption capacity of alluvial soils (Sakadevan and others 1999). A key question is how a lack of heavy-metal sequestration would affect nitrogen cycling processes downstream.

A second challenge concerns the scale of appraisal of water regime change effects on nutrient cycling. Depending of the spatial and temporal monitoring scale, the consequences of water regime changes on gaseous nitrogen end products varies (Bodelier and others 2000). Contrasting field and laboratory results on the respective importance of different processes on end products appears to result from the difference of space and time scale at which the studies were conducted.

The issue of scale can be illustrated by examining the regulation of nitrogen gas production via nitrification and denitrification, which occurs at two contrasting levels. The first level relates to control of process rates, and the second level relates to control of the relative proportion of end products. At the bacterial level nitrification rates are controlled primarily by $\mathrm{O}_{2}$ and $\mathrm{NH}_{4}$ availability. Similarly, denitrification is affected primarily by $\mathrm{O}_{2}, \mathrm{NO}_{3}$, and organic $\mathrm{C}$ availability (Firestone and Davidson 1989). The relationship between ecosystem properties and factors affecting relative proportions of the end products and gaseous intermediary compounds is less well understood. However, these gaseous intermediary compounds (i.e., $\mathrm{NO}$ and $\mathrm{N}_{2} \mathrm{O}$ ) are of serious concern since they contribute to the greenhouse effect (Wayne 1993). Both nitrification and denitrification processes produce gaseous forms of $\mathrm{NO}_{x}$ (Stevens and others 1997). Yet, the respective contribution of nitrification and denitrification to atmospheric $\mathrm{N}_{2} \mathrm{O}$ is still controversial. Production of $\mathrm{N}_{2} \mathrm{O}$ by nitrifying bacteria results from reduction of $\mathrm{NO}_{2}$ when oxygen is limiting. Production of $\mathrm{N}_{2} \mathrm{O}$ during denitrification is affected by the relative availability of electron donors and acceptors. For example, it is known that the rate of $\mathrm{N}_{2} \mathrm{O}$ production is significantly greater in the wetter soil than in drier soil (Webster and Hopkins 1996). However, because $\mathrm{N}_{2} \mathrm{O}$ consumption by denitrifiers is also greater in the wet soils, the net $\mathrm{N}_{2} \mathrm{O}$ emissions from the wetter and the drier soils do not differ significantly.

Despite these uncertainties, it has been proposed that the best option to maintain high $\mathrm{NO}_{3}$ removal rates and to reduce the proportion of $\mathrm{N}_{2} \mathrm{O}$ in the emitted gases is to maintain a high water table for a prolonged period in the most biologically active portion of soil profiles (Jacinthe and others 2000). Furthermore, in permanently water-covered riparian areas, 
denitrification can serve as a sink for both dissolved $\mathrm{N}_{2} \mathrm{O}$ in the groundwater recharging the area and for $\mathrm{N}_{2} \mathrm{O}$ produced within the riparian sediment (BlitcherMathiesen and Hoffmann 1999). Lowering the water table in riparian wetlands may increase $\mathrm{N}_{2} \mathrm{O}$ emission but would reduce NO emission (Ren and others 2000). The extent to which the increase of oxic soil depth would limit the $\mathrm{N}_{2} \mathrm{O}$ and $\mathrm{NO}$ emission by microbial oxidation requires further attention.

Another issue is related to the determination of the respective roles of human impacts and natural changes on river ecosystem functions (Vitousek and others 1997). In most cases, pristine ecosystems are in different ecoregions than human impacted ones, limiting the ability to extrapolate process rates and trends from natural to modified systems (Tol and Langen 2000). However, in both cases, the main principles regulating the cycling and transfer of nitrogen in river ecosystems remain valid despite differences in process rates. Therefore, sustainable management practices should be assessed according their impact on (1) the delivery mode of nitrogen to river ecosystems; (2) the length of contact between water, soil, and sediment; and (3) the timing, intensity, and duration of floods and drought.

\section{Acknowledgments}

We thank M. M. Brinson and an anonymous reviewer for their constructive comments on an earlier version of the manuscript. Financial support was provided by the Scientific Committee for Water Research (SCOWAR) of the International Council for Science (ICSU), by the National Center for Ecosystem Analyses and Synthesis (NCEAS), Santa Barbara, California, USA, and by a pan-European project on nitrate buffer zones, and the NICOLAS (Nitrogen Control by Landscape Structures in Agricultural Environments) project funded by the European Commission DG XII (Scientific Adviser H. Barth), grant number ENV4-CT97-0395.

\section{Literature Cited}

Abdelhafid, R., S. Houot, and E. Barriuso. 2000. Dependence of atrazine degradation on $\mathrm{C}$ and $\mathrm{N}$ availability in adapted and non-adapted soils. Soil Biology Biochemistry 32:389-401.

Alexander, R. B., R. A. Smith, and G. E. Schwartz. 2000. Effect of stream channel size on the delivery of nitrogen to the Gulf of Mexico. Nature 403:758-761.

Beven, K., and M. J. Kirkby. 1979. A physically based, variable contributing area model of basin hydrology. Hydrological Sciences Bulletin 24:43-69.

Blitcher-Mathiesen, G., and C. C. Hoffmann. 1999. Denitrification as a sink for dissolved nitrous oxide in freshwater riparian fen. Journal of Environmental Quality 28:257-262.
Bodelier, P. L. E., A. H. Hahn, I. R. Arth, and P. Frenzel. 2000. Effects of ammonium-based fertilisation on microbial processes involved in methane emission from soil planted with rice. Biogeochemistry 51:225-257.

Brinson, M. M. 1993. Changes in the functioning of wetlands along environmental gradients. Wetlands 13:65-74.

Brinson, M. M., H. D. Bradshaw, and R. N. Holmes. 1983. Significance of floodplain sediments in nutrient exchange between a stream and its floodplain. Pages 199-220 in Dynamics of lotie ecosystems. Ann Arbor Science, Michigan, T. D. Fontaine, and S. M. Bartel (eds.), Ann Arbor.

Brinson, M. M., H. D. Bradshaw, and E. S. Kane. 1984. Nutrient assimilative capacity of an alluvial floodplain swamp. Journal of Applied Ecology 21:1041-1057.

Brunet, R. C., G. Pinay, F. Gazelle, and L. Roques. 1994. The role of floodplain and riparian zone in suspended matter and nitrogen retention in the Adour River, southwest France. Regulated Rivers: Research and Management 9:55-63.

Burt, T. P. 1997. The hydrological role of floodplain within the drainage basin system. Pages 21-32 in N. E. Haycock, T. P. Burt, K. W. T. Goulding, and G. Pinay (eds.), Buffer zones: Their processes and potential in water protection. Quest Environmental Publications, Harpenden, UK.

Chauvet, E. 1987. Changes in the chemical composition of alder, poplar and willow leaves during decomposition in a river. Hydrobiologia 148:35-44.

Clark, G. M., D. K. Mueller, and M. A. Mast. 2000. Nutrient concentrations and yields in undeveloped stream basins of the United States. Journal of the American Water Resources Association 36:849-860.

Cummins, K. W., J. R. Sedell, F. J. Swanson, G. W. Minshall, S. G. Fisher, C. E. Cushing, R. C. Peterson, and R. L. Vannote. 1983. Organic matter budgets for stream ecosystems: Problems in their evaluation. Pages 299-353 in J. R. Barnes, and G. W. Minshall (eds.), Stream ecology. Plenum Press, New York.

Décamps, H. 1993. River margins and environmental change. Ecological Applications 3:441-445.

Décamps, H. 1996. The renewal of floodplains forests along rivers: a landscape perspective. Verhandlungen der Internationalen Vereinigung für Theoretische and Angewandte Limnologie 26:35-59.

Décamps, H., G. Pinay, R. J. Naiman, G. E. Petts, M. E. McClain, A. Hillbricht-Ilkowska, T. A. Hanley, R. M. Holmes, J. Quinn, J. Gibert, A. M. P. Tabacchi, F. Schiemer, E. Tabacchi, and M. Zalewski. 2002. Riparian zones: Where biogeochemistry meets biodiversity in management practice. River Research and Application (in press).

Dynesius, M., and C. Nilsson. 1994. Fragmentation and flow regulation of rivers systems in the northern third of the world. Science 266:753-762.

Edwards, R. T. 1998. The hyporheic zone. Pages 399-429 in R. J. Naiman, and R. E. Bilby (eds.), River Ecology and Management: Lessons from the Pacific Coastal Ecoregion. Springer, New York.

Elwood, J. W., J. D. Newbold, R. V. O’Neill, and W. V. Winkle. 1983. Resource spiraling: An operational paradigm for analysing lotic ecosystems. Pages 3-27 in T. D. Fontaine III, and 
S. M. Bartell (eds.), Dynamics of lotie ecosystems. Ann Arbor Science, Ann Arbor, Michigan.

Evans, R. 1990. History of the Nile flows. Pages 5-39 in P. P. Howell, and J. A. Allan (eds.), The Nile. School of Oriental and African Studies, Royal Geographical Society, London.

Firestone, M. K., and E. A. Davidson. 1989. Microbial basis of $\mathrm{NO}$ and $\mathrm{N} 2 \mathrm{O}$ production and consumption in soil. Pages 7-21 in M. O. Andreae, and D. S. Schimel (eds.), Exchange of trace gases between terrestrial ecosystems and the atmosphere: Report of the Dahlem workshop on exchange of trace gases between terrestrial ecosystems and the atmosphere, 19-24 February 1989, Berlin. John Wiley \& Sons, Chichester, UK.

Graf, W. L. 1999. Dam nation: A geographic census of American dams and their large scale hydrologic impacts. Water Resources Research 35:1305-1311.

Gregory, S. V., F. J. Swanson, W. A. McKee, and K. W. Cummins. 1991. An ecosystem perspective of riparian zone. BioScience 41:540-550.

Gresh, T., J. Lichatowich, and P. Shoonmaker. 2000. An estimation of historic and current levels of salmon production in the northeast Pacific ecosystems: Evidence of a nutrient deficit in the freshwater systems of the Pacific Northwest. Fisheries 25:15-21.

Groffman, P. M., and G. C. Hanson. 1997. Wetland denitrification: influence of site quality and relationships with wetland delineation protocols. Soil Science Society of America Journal 61:323-329.

Groffman, P. M., and J. M. Tiedje. 1988. Denitrification hysteresis during wetting and drying cycles in soil. Soil Science Society of America Journal 52:1626-1629.

Groot, C., and L. Margolis (eds.). 1991. Pacific salmon life histories. University of British Columbia Press, Vancouver, Canada.

Grubaugh, J. W., and R. V. Anderson. 1989. Upper Mississippi River: Seasonal and floodplain forest influences on organic matter transport. Hydrobiologia 174:235-244.

Haque, C. E., and M. Q. Zaman. 1993. Human responses to riverine hazards in Bangladesh: A proposal for sustainable floodplain development. World Development 1:93-107.

Haycock, N. E., and G. Pinay. 1993. Groundwater nitrate dynamics in grass and poplar vegetated riparian buffer strips during the winter. Journal of Environmental Quality 22:273-278.

Haycock, N. E., T. P. Burt, K. W. T. Goulding, and G. Pinay (eds.). 1997. Buffer zones: Their processes and potential in water protection. Quest Environmental, Harpenden, UK, 320 pp.

He, Q., and D. E. Walling. 1997. Spatial variability of the particle size composition of overbank floodplain deposits. Water, Air and Soil Pollution 99:71-80.

Hedin, L. O., J. C. Vonfischer, N. E. Ostrom, B. P. Kennedy, M. G. Brown, and G. P. Robertson. 1998. Thermodynamic constraints on nitrogen transformations and other biochemical processes at soil-stream interfaces. Ecology 79:684703.

Helfield, J. M., and R. J. Naiman. 2001. Effects of salmon- derived nitrogen on riparian forest growth and implications for stream habitat. Ecology 82:2403-2409.

Hill, A. R. 1979. Denitrification in the nitrogen budget of a river ecosystem. Nature 281:291-292.

Hill, A. R., K. J. Devito, S. Campagnolo, and K. Sanmugadas. 2000. Subsurface denitrification in a forest riparian zone: Interactions between hydrology and supplies of nitrate and organic carbon. Biogeochemistry 51:193-223.

Holmes, R. M., S. G. Fisher, and N. B. Grimm. 1994. Parafluvial nitrogen dynamics in a desert stream ecosystem. Journal of the North American Benthological Society 13:468-478.

Hynes, H. B. N. 1975. The stream and it's valley. Verhandlungen der Internationalen Vereinigung für Theoretische und Angewandte Limnologie 19:1-15.

Jacinthe, P. A., W. A. Dick, and L. C. Brown. 2000. Bioremediation of nitrate-contaminated shallow soils and waters via water table management techniques: Evolution and release of nitrous oxide. Soil Biology Biochemistry 32:371-382.

Jones, J. B., and R. M. Holmes. 1996. Surface-subsurface interactions in stream ecosystems. Trends in Ecology and Evolution 11:239-242.

Juday, C., W. H. Rich, G. I. Kemmener, and A. Mean. 1932. Limnological studies of Karluk Lake, Alaska 1926-1930. Bulletin of US Bureau of Fisheries 47:407-436.

Junk, B., P. B. Bayley, and R. E. Sparks. 1989. The flood pulse concept in river-floodplain systems. Fisheries and Aquatic Sciences 106:110-127.

Keeney, D. R. 1973. The nitrogen cycle in sediment-water systems. Journal of Environmental Quality 2:15-29.

Lowrance, R., R. Leonard, and J. Sheridan. 1985. Managing riparian ecosystems to control nonpoint pollution. Journal of Soil and Water Conservation 40:87-91.

Lowrance, R., K. Sharpe, and J. M. Sheridan. 1986. Long term sediment deposition in the riparian zone of a coastal plain watershed. Journal of Soil and Water Conservation 41:266-271.

Lowrance, R., L. S. Altier, J. D. Newbold, R. R. Schnabel, P. M. Groffman, J. M. Denver, D. L. Correll, J. W. Gilliam, J. L. Robinson, R. B. Brinsfield, K. W. Staver, W. C. Lucas, and A. H. Todd. 1995. Water quality functions of riparian forest buffer systems in the Chesapeake Bay Watersheds. US Environmental Protection Agency, Chesapeake Bay Program Report. US EPA Region 3 Chesapeake Bay Program Office, Annapolis, Maryland, 67 pp. EPA 903-R-95-004.

Lowrance, R., L. S. Altier, J. D. Newbold, R. R. Schnabel, P. M. Groffman, J. M. Denver, D. L. Correll, J. W. Gilliam, J. L. Robinson, R. B. Brinsfield, K. W. Staver, W. Lucas, and A. H. Todd. 1997. Water quality functions of riparian forest buffers in Chesapeake Bay watersheds. Environmental Management 21:687-712.

Matchett, L. S. 1998. Denitrification in riparian buffer zones. PhD dissertation, University of Oxford, Oxford, UK.

Mathab, F. U., and Z. Karim. 1992. Population and agricultural land use: towards a sustainable food production system in Bangladesh. Ambio 21:50-55.

McClain, M. E., J. E. Richey, J. A. Brandes, and T. P. Pimentel. 1997. Dissolved organic matter and terrestrial-lotic linkages in the central Amazon basin of Brazil. Global Biogeochemical Cycles 11:295-311. 
Meybeck, M. 1982. Carbon, nitrogen, and phosphorus transport by world rivers. American Journal of Science 282:401-450.

Minshall, G. W., R. C. Petersen, K. W. Cummins, T. L. Bott, J. R. Sedell, C. E. Cushing, and R. L. Vanotte. 1983. Interbiome comparison of stream ecosystem dynamics. Ecological Monographs 53:1-25.

Naiman, R. J. 1983. The annual pattern and spatial distribution of aquatic oxygen metabolism in boreal forest watersheds. Ecological Monographs 53:73-94.

Naiman, R. J., and H. Décamps. 1997. The ecology of interfaces: riparian zones. Annual Review of Ecology and Systematics 28:621-658.

Neill, C. 1995. Seasonal flooding, nitrogen mineralization and nitrogen utilization in a prairie marsh. Biogeochemistry 30: 171-189.

Newbold, J. D., J. W. Elwood, R. V. O'Neill, and W. Van Winkle. 1981. Measuring nutrient spiralling in streams. $C a-$ nadian Journal of Fisheries and Aquatic Sciences 38:860-863.

Nixon, S. W., J. W. Ammerman, L. P. Atkinson, V. M. Berounsky, G. Billen, W. C. Boicourt, W. R. Boyton, T. M. Church, D.M. Ditoro, R. Elmgren, J. H. Garber, A. E. Giblin, R. A. Jahnke, N. P. J. Owens, M. E. Q. Pilson, and S. P. Seitinger. 1996. The fate of nitrogen and phosphorus at the land-sea margin of the North Atlantic Ocean. Biogeochemistry 35:141180.

Osborne, L. L., and M. J. Wiley. 1988. Empirical relationships between land use cover and stream water quality in an agricultural watershed. Journal of Environmental Management 26:9-27.

Patrick, W. J. 1982. Nitrogen transformations in submerged soils. Agronomy Monograph 22:449-765.

Paul, E. A., and F. E. Clark. 1996. Soil microbiology and biochemistry. Academic Press London.

Peterjohn, W. T., and D. L. Correll. 1984. Nutrient dynamics in an agricultural watershed: Observations on the role of a riparian forest. Ecology 65:1466-1475.

Peterson, B. J., W. H. Wollheim, P. J. Mulholland, J. R. Webster, J. L. Meyer, J. L. Tank, E. Marti, W. B. Bowden, H. M. Valett, A. E. Hershey, W. H. McDowell, W. K. Dodds, S. K. Hamilton, S. Gregory, and D. J. Morrall. 2001. Control of nitrogen export from watersheds by headwater streams. Science 292:86-90.

Petts, G. E. 1990. Regulation of large rivers: problems and possibilities for environmentally sound river development in South America. Interciencia 15:388-395.

Petts, G. E., and I. Maddock. 1996. Flow allocation for in-river needs. Pages 60-79 in G. E. Petts, and P. P. Calow (eds.), River restoration. Blackwell Sciences, London.

Pinay, G., and L. Labroue. 1986. Une station d'épuration naturelle des nitrates transportés dans les nappes alluviales: l'aulnaie glutineuse. Comptes Rendus de l'Académie des Sciences de Paris, série III, 302 III:629-632.

Pinay, G., and R. J. Naiman. 1991. Short term hydrologic variations and nitrogen dynamics in beaver created meadows. Archiv für Hydrobiologie 123:187-205.

Pinay, G., H. Décamps, C. Arles, and M. Lacassin-Seres. 1989. Topographic influence on carbon and nitrogen dynamics in riverine woods. Archiv für Hydrobiologie 114:401-414.
Pinay, G., L. Roques, and A. Fabre. 1993. Spatial and temporal patterns of denitrification in a riparian forest. Journal of Applied Ecology 30:581-591.

Pinay, G., C. Ruffinoni, and A. Fabre. 1995. Nitrogen cycling in two riparian forest soils under different geomorphic conditions. Biogeochemistry 4:1-21.

Pinay, G., V. J. Black, A. M. Planty-Tabacchi, B. Gumiero, and H. Décamps. 2000. Geomorphic control of denitrification in large river floodplain soils. Biogeochemistry 30:9-29.

Ponnamperuma, F. N. 1972. The chemistry of submerged soils. Advances in Agronomy 24:29-96.

Pringle, C. M., M. C. Freeman, and B. J. Freeman. 2000. Regional effects of hydrologic alterations on riverine macrobiota in the New World: tropical-temperate comparisons. BioScience 50:807-820.

Ranjard, L., F. Poly, J. Combrisson, A. Richaume, F. Gourbière, J. Thioulouse, and S. Nazaret. 2000. Heterogeneous cell density and genetic structure of bacterial polls associated with various soil microenvironments as determined by enumeration and DNA fingerprinting approach (RISA). Microbial Ecology 39:263-272.

Reddy, K. R., and W. H. Patrick. 1975. Effect of alternate aerobic and anaerobic conditions on redox potential, organic matter decomposition and nitrogen loss in a flooded soil. Soil Biology and Biochemistry 7:87-94.

Ren, T., R. Roy, and R. Knowles. 2000. Production and consumption of nitric oxide by three methanotrophic bacteria. Applied of Environmental Microbiology 66:3891-3897.

Richter, B. D., and H. E. Richter. 2000. Prescribing flood regimes to sustain riparian ecosystems along meandering rivers. Conservation Biology 15:1467-1478.

Roberts, J., and J. A. Ludwig. 1991. Riparian vegetation along current-exposure gradients in floodplain wetlands of the River Murray, Australia, Journal of Ecology 79:117-127.

Sakadevan, K., H. Zheng, and H. J. Bavor. 1999. Impact of heavy metals on denitrification in surface wetland sediments receiving wastewater. Water Sciences and Technology 40:349-355.

Salo, J., R. Kalliola, J. Häkkinen, Y. Mäkinen, P. Niemelä, M. Puhakka, and P. B. Coley. 1986. River dynamics and the diversity of Amazon lowland forest. Nature 332:254-258.

Schlosser, I. J., and J. R. Karr. 1981. Riparian vegetation and channel morphology impact on spatial patterns of water quality in agricultural watersheds. Environmental Management 5:233-243.

Shield, F. D., A. Simon, and L. J. Steffen. 2000. Reservoir effects on downstream river channel migration. Environmental Conservation 27:54-66.

Sparks, R. E. 1995. Need for ecosystem management of large rivers and their floodplains. BioScience 45:169-182.

Stanford, J. A., and J. V. Ward. 1988. The hyporheic communities of two Montana rivers. Nature 335:64-66.

Stepanauskas, R., H. Laudon, and N. O. G. Jorgensen. 2000. High DON bioavailability in boreal streams during a spring flood. Limnology and Oceanography 45:1298-1307.

Stevens, R. J., R. J. Laughlin, L.C. Burns, J. R. M. Arah, and R. Hood. 1997. Measuring the contributions of nitrification 
and denitrification to the flux of nitrous oxide from soil. Soil Biology Biochemistry 29:139-151.

Tabacchi, E., D. L. Correll, R. Hauer, G. Pinay, A. M. PlantyTabacchi, and R. C. Wissmar. 1998. Development, maintenance and role of riparian vegetation in the river landscape. Freshwater Biology 40:497-516.

Tol, R. S. J., and A. Langen. 2000. A concise history of dutch river floods. Climate Change 46:357-369.

Triska, F. J., V. C. Kennedy, R. J. Avanzino, G. W. Zellweger, and K. E. Bencala. 1989. Retention and transport of nutrients in a third-order stream in northwestern California: Hyporheic processes. Ecology 70:1893-1905.

Triska, F. J., J. H. Duff, and R. J. Avanzino. 1990. Influence of exchange flow between the channel and hyporheic zone on nitrate production in a small mountain stream. Canadian Journal of Fisheries and Aquatic Sciences 47:2099-2111.

Triska, F. J., J. H. Duff, and R. J. Avanzino. 1993. Patterns of hydrological exchange and nutrient transformation in the hyporheic zone of a gravel-bottom stream: Examining terrestrial-aquatic linkages. Freshwater Biology 29:259-274.

Tufford, D. L., H. N. McKellar, Jr., and J. R. Hussey. 1998. In-stream non point source nutrient prediction with landuse proximity and seasonality. Journal of Environmental Quality 27:100-111.

Vadineanu, A., S. Cristofor, D. Nicolescu, C. Dorobantu, and L. Gavrila. 1987. Biodiversity changes along the Lower Danube River System. International Journal of Ecology and Environmental Sciences 24:315-332.
Valett, H. M., J. A. Morrice, C. N. Dahm, and M. E. Campana. 1996. Parent lithology, surface-groundwater exchange and nitrate retention in headwater streams. Limnology and Oceanography 41:333-345.

Vitousek, P. M., J. D. Aber, R. W. Howarth, G. E. Likens, P. A. Matson, D. W. Schindler, W. H. Schlesinger, and D. G. Tilman. 1997. Human alteration of the global nitrogen cycle: Sources and consequences. Ecological Applications $7: 737-750$.

Ward, J. V. 1989. The four-dimensional nature of lotic ecosystems. Journal of the North American Benthological Society 8:2-8.

Wayne, R. P. 1993. Nitrogen and nitrogen compounds in the atmosphere. Pages 23-38 in T. P. Burt, A.L. Heathwaite, and S. T. Trudgill (eds.), Nitrate: Processes patterns and management. John Wiley \& Sons, London.

Webster, E. A., and D. W. Hopkins. 1996. Contributions from different microbial processes to $\mathrm{N}_{2} \mathrm{O}$ emissions from soil under different moisture regimes. Biology and Fertility of Soils 22:331-335.

Wollheim, W. M., B. J. Peterson, L. A. Deegan, J. E. Hobbie, B. Hooker, W. B. Bowden, K. J. Edwardson, D. B. Arscott, A. E. Hershey, and J. Finlay. 2001. Influence of stream size on ammonium and suspended particulate nitrogen processing. Limnology and Oceanography 46:1-13.

Worrall, F., and T. P. Burt. 1998. Decomposition of river nitrate time-series. Comparing agricultural and urban signals. The Science of the Total Environment 210/211:153-162. 